\title{
Investigating the Attitudes of ESL Learners Towards Native and Non-native Variety of English Accent: A Study of Public Sector University of Sindh, Jamshoro and the Shaheed Benazir University of Nawabshah
}

\author{
Isra Shaikh \\ ELDC, Mehran Engineering and Technology University, Jamshoro
}

\begin{abstract}
The present study investigates the attitude of English Language Learners towards notion of World Englishes. This study in-depth explores the attitudes of ESL towards native and non-native varieties of English language. The researcher has chosen the three varieties of English language; two native varieties and one non-native variety of English language. The two native varieties are; American and British English and one non-native variety is Pakistani English. The researcher is interested in investigating the attitude towards accent of these varieties particularly. The study employed quantitative methodology and 100 students were chosen from English department of two Universities; University of Sindh and Shaheed Benazir Bhutto University of Nawabshah. The data showed that ESL have positive inclination towards native varieties and they want to sound like a native speaker.
\end{abstract}

Keywords: World Englishes, Accent, Attitudinal Study, Non-native Variety, Native Varieties, Pakistani English. DOI: $10.7176 /$ JLLL/83-05

Publication date: November $30^{\text {th }} 2021$

\section{Introduction}

Throughout history, English has advanced from essentially a tribal language to the situation with a world language. English is the main language that has more Non-local speakers. English language has turned into a worldwide language which fills the need of most widely used language. Nobody can deny from this reality that the English language at present partakes in a general belonging (Schneider 2003).

\section{Status of English Language}

English is an overall language that has a remarkable status all through the world. It is the language of millions of people all throughout the world. English is known as the most broadly utilized language all through the world. English is an all-inclusive language and it used by and large all through the world on the grounds that the example of imparting in English is extending bit by bit and the people have started using English in their step by step correspondence.

At the point when they use it in a non-local setting it develops different variants of reoriented language. English has gotten a predominant situation in Pakistan. It doesn't assist with being capable. However, it is seen as the sign of status, authority, and social matchless quality (Krikpatric, 2009).

This view that someone doesn't have the foggiest idea about the English language, it is incomprehensible for him to get a high status in the public eye. By far most of the people in Pakistan convey in English just to bestow. Pakistani English is an acknowledged variety however it is obscure to many individuals. It is a NonNative variety so it is relying upon the socio and political elements of the nation (Ghani, 2005).

\section{Significance of Research}

English is the most communicated language and has accomplished importance in the world and turned into a most widely used language. As Widdowson (1994) states that English has a place with local speakers as well as Non-local speakers. With the worldwide acknowledgment of World Englishes, there are many investigations has been analyzed the perspectives of students towards various varieties of World Englishes.

Pakistani English turned into the acknowledged variety of World Englishes which has fostered its elements. This paper discusses the importance of Pakistani English and investigates the attitudes of English language learners towards the Pakistani English variety and assists them with perceiving the significance of Pakistani English.

This research gives an overall outline of varieties of World Englishes and features the Pakistani English as a perceived Variety of World Englishes. This would help the English Language Learners to claim their Pakistani English as a perceived variety and it assists me with passing on this message that communicate in English with certainty regardless of which accent you are following. 


\section{Research Objectives}

$>\quad$ To investigate the attitudes of ESL Students of the English department of the University of Sindh and the Shaheed Benazir Bhutto University of Nawabshah towards native varieties of English accent. (British and American)

$>\quad$ To investigate the attitudes of ESL Learners of the English department of the University of Sindh, Jamshoro, and Shaheed Benazir Bhutto University of Nawabshah towards a non-native variety of English accents. (Pakistani English)

- To investigate that to what extent ESL Learners of the English department of the University of Sindh and Shaheed Benazir are motivated to learn Pakistani English.

\section{Research Questions:}

RQ1: What are the attitudes of ESL Learners of the English Department of the University of Sindh and Shaheed Benazir Bhutto University towards native varieties of English accents? (British and American)

RQ2: What are the attitudes of ESL Learners of the English department of the University of Sindh Jamshoro and Shaheed Benazir Bhutto University of Nawabshah towards a non-native variety of English accents? (Pakistani English)

RQ3: To what extent ESL Learners of the English department of the University of Sindh and Shaheed Benazir are motivated to learn Pakistani English.

\section{Literature Review \\ Language Attitudes}

Language attitudes are the opinions or feelings people have about their language (Crystal 1992). Every individual possess language sentiment towards their language and many researchers have been discussed the attitudes of language learners towards specific language.

Attitudes towards the English language have been investigated internationally over continuous many years.

\section{World Englishes and Learner's Attitude Towards it}

Widdowson (1994) states that English language isn't an ownership of local speakers in particular, others also own it as indicated by their own persuasive structure and culture.

$\mathrm{He}$ and $\mathrm{Li} \mathrm{(2009)}$ investigated the attitudes of Chinese learners toward China English. The results displayed that these individuals were hopeful with regards to their own variety of English language; China English. He and $\mathrm{Li}$ (2009) reasoned that Chinese learners had an inspirational perspective towards China English.

Afnan Almegren (2018) examined Saudi Learner's perspectives towards World Englishes. He observed that Saudi students knew about the term 'World Englishes' and various varieties of it yet they considered British English as Standard English and needs to get familiar with the language like local speakers.

\section{English language In Pakistan}

English is the authority language of Pakistan and furthermore the second language of the country. It is generally utilized by a lot of populaces of Pakistan. It is additionally important for our educational plan (Raza, 2008). As shown by Ghani (2003:105) English language is a way towards the advancement and to find a middle class line of work.

\section{World Englishes In Global Context}

The term socio-linguistics can be characterized as a connection among language and society. It investigates the variables and causes that how language fills in the general public. Socio-political includes both social and political variables which influence the language. In this study, the researcher is intrigued to realize which variables influence the decision of language among college students and how these elements shape their thoughts.

\section{Theoretical Framework}

In this study, the researcher uses the Kachru's concentric model. This model is based on the assumption made by Kachru (1985), in which he divided the countries into three groups: inner, outer and expanding circle. Kachru stated that the inner circle includes the native speakers of the English language. Outer circle includes the countries where people speak the English language as a second language. The expanding circle is those areas where the English language serves as a foreign language. Pakistan falls in the category of outer circle where English is an official and second language of the nation.

\section{Research Methodology}

For this study, Quantitative methodology has been adopted. Creswell (2002) defines quantitative methodology as 
the process of collecting the data then analyze it and further interpret in according to the obtained results.

\section{Research Design}

A Cross-Sectional Survey research design has been adopted for this study. Survey research can be defined as a procedure in which the researcher analyzes the attitudes, opinions, or behavior of the entire population. In crosssectional design, data can be collected at one point in time.

\section{Research Instrument}

In this research, the researcher will adopt a questionnaire. The researcher will use the 'A Study on Attitudes towards varieties of spoken English in Pakistani context' designed by Sabahat Parveen (2013) and some number of items would be adopted from Joel Magogwe's (1995) study 'An investigation of Language attitudes in relation of language use: Botswana Cambridge Learners' designed by Sue.

The researcher uses the two different questionnaires in this study. Magogwe's adopted tool helps the researcher to analyze the last research question and both tools support each other.

\section{Sampling}

Sampling is a technique to recruit participants for the study. The present study uses random sampling which can be defined as a method in which all participants of a group have an equal and independent chance of being selected (Creswell, 2009).

\section{Participants of the Study}

The participants in this study will be 300 students. The students are randomly chosen from the third and final year of the English department, University of Sindh, Jamshoro and SBBU of Nawabshah.

\section{Data Analysis}

The researcher has analyzed the data through SPSS software in terms of percentage using descriptive statistics analysis. In this analysis, researcher simply describes the data and summarize it. The researcher analyze the data through descriptive analysis using Mean, Median and interval data analysis.

\section{Research Ethics}

Ethics could be commonly explained as " in what way we behave or have to behave in relation to the people with whom we meet or interact " (Simons, 2009: 96). The data will be collected with the consent of the participants and they would be aware of their ethical considerations.

\section{Conclusion}

This research paper concludes that ESL learners have positive inclination towards native varieties and they want to sound like a native speaker. However, they are aware of the term World Englishes and acknowledge the Pakistani English variety but they consider native English as a Standard English language.

\section{Limitation of the Study}

This study provides some general and specific information about the attitudes of University students towards Pakistani English in Jamshoro, University of Sindh.

Whereas, we can further carry out this study to measure the attitude of Medical and Engineering students towards World Englishes and particularly Pakistani English.

Another limitation of this study is that it does not capture any change in attitudes. Attitudes, in nature, are not static but change (Baker, 1992). However, future study can be conducted which can described the change in attitudes as the data collected in this study is based on specific time frame.

\section{References}

Almegnen, Afnan. 2018. Saudi Student's Attitude Toward World Englishes.

Arrieta, Marie. 2017. Teacher's and Student's Perception of World Englishes Pronunciation In Two US setting.

Baumgardner, Robert J. (1990) The indigenization of English in Pakistan. English Today 6(1), 59-65.

Baumgardner, R. J. (1993). The English language in Pakistan. Oxford University Press.

Bolton, K. (2004). World Englishes. In A. Davies, \& C. Elder (Eds.), The handbook of applied linguistics.

Bolton, Kingsley (2000) The sociolinguistics of Hong Kong and the space Hong Kong English. World Englishes, 19(3), pp. 265-85

Baker, C. (1988). Key issues in bilingualism and bilingual education. Clevedon: Multilingual Matters. 367-396). Blackwell Publishing Ltd.

Canagarajah, A. Suresh (1994) Competing discourses in Sri Lankan English 
poetry. World Englishes, 13(3), 361-76. Attitudes toward English in Malaysia. World Englishes, 15 (3), 319-335.

Crystal, D. (1988). The English language. London: Penguine Books Ltd. Crystal, D. (2004). The language revolution. Wiley- Blackwell.

Crystal, D. 1966.The Linguistic Status of Prosodic and Paralinguistic Features. Proceedings of the University of Newcastle-upon Tyne Philosophical Society: Vol. 1, 93-108.

Crystal, D. 2003. English as a Global Language (Second ed.). Cambridge: Cambridge University Press.

De Kadt, E. (1993). Attitudes towards English in South Africa. World Eglishes , 12 (3), 311- 324.

Edwards, J. R. 1982. Language Attitudes and their Implications among English Speakers. In Ryan, E.B. \& Giles, H. (eds.) Attitudes toward Language Variation. Social and Applied Contexts. London: Edward Arnold.

Ghani, M. (2003). The status and position of English language in Pakistan. Journal of Social sciences and Humanities, 1 (1), 103-115.

Gerring, J. (2007). Case study research, principles and practices. Cambridge university Press. Graddol, D (1997). The Future of English? London: The British Council.

Graddol, D. (1999). The decline of the native speaker. AILA Review, 13, 57-68.

Haque, R. 1983. The position and status of English in Pakistan. World Language English 2(1).

Hundt, Marianne (1998) New Zealand English Grammar, Fact or Fiction? A Corpus- Based Study in Morphosyntactic Variation. In the series Varieties of English Around the World.

Vol. 23. Philadelphia: John Benjamins.

Jenkins, J. (1998). Which pronunciation norms and models for English as an international language? ELT Journal, 52(2), 119-126.

Jenkins, J. (2000). The Phonology of English as an International Language. Oxford: Oxford University Press.

Jenkins, J. (2002). A sociolinguistic ally based, empirically researched pronunciation syllabus for English as an international language. Applied Linguistics, 23(1), 83-103.

Jenkins, K. 2005. Implementing an international approach to English pronunciation: the role of teacher attitudes and identity.

Kachru, B. (1985). Standards, codification and sociolinguistic realism: the English language in the outer circle. In R. Quirk \& H. G. Widdowson (Eds.), English in the World: Teaching and Learning the Language and Literatures (pp. 11-30). Cambridge: Cambridge University Press.

Rahman, T. (2002). Language, ideology and power: Language learning among the Muslims of Pakistan and North India. Karachi: Oxford University Press.

Mansoor, S. 2005. Language Planning in Higher Education: A Case Study. Karachi: Oxford University Press.

Phillipson, R. 2009. Linguistic Imperialism Continued. Hyderabad, India: Orient BlackSwan.

Rassool, N. and Mansoor, S. 2009. Contemporary issues in language, education and development in Pakistan. In N. Rasool (ed.), Global Issues in Language, Education and Development: Perspectives from Post-colonial Countrie, 218-244. New Delhi: Orient Longman.

Shamim, F. 2007a. English as the language for development in Pakistan: Issues, challenges and possible solutions.

Soomro, Niaz. 2016. Towards an Understanding of Pakistani Undergraduates' Current Attitudes towards Learning and Speaking English.

Rahman, T. 2002. Language, Ideology and Power. Karachi: Oxford University Press. Rahman, A. M. M. Hamidur (1996) Acceptability and English curriculum change in

Bangladesh. In South Asian English: Structure, Use, and Users. Edited by Robert J. Baumgardner. Urbana: University of Illinois Press, pp. 191-205.

Rahman, Tariq (1990) Pakistani English: The Linguistic Description of a Non-Native Variety of English. NIPS Monograph Series III. Islamabad: National Institute of Pakistan Studies. (c) 2011 Hong Kong University Press.

Raza. Muhammad. 2015. Language Attitude and English Language Learning In Pakistan. Yu, Yang. 2010. Attitudes of Learners Toward English: A Case of Chinese College Students. 